$\begin{array}{ll} & \text { Etnográfica } \\ \text { etnográfica } & \text { Revista do Centro em Rede de Investigação em }\end{array}$

Antropologia

vol. 22 (1) | 2018

Vol. 22 (1)

\title{
Political community and transnational citizenship: ethnographic perspectives on a heterogeneous articulation
}

Comunidade politica e cidadania transnacional: perspetivas etnográficas sobre uma articulação heterogénea

\section{Silvina Merenson}

\section{(2) OpenEdition}

\section{Journals}

Electronic version

URL: https://journals.openedition.org/etnografica/5191

DOI: 10.4000/etnografica. 5191

ISSN: 2182-2891

\section{Publisher}

Centro em Rede de Investigação em Antropologia

\section{Printed version}

Date of publication: 1 February 2018

Number of pages: 149-167

ISSN: 0873-6561

\section{Electronic reference}

Silvina Merenson, "Political community and transnational citizenship: ethnographic perspectives on a heterogeneous articulation", Etnográfica [Online], vol. 22 (1) | 2018, Online since 17 May 2018,

connection on 21 January 2022. URL: http://journals.openedition.org/etnografica/5191 ; DOI: https:// doi.org/10.4000/etnografica.5191

\section{(c) (†) 8}

Etnográfica is licensed under a Creative Commons Attribution-NonCommercial 4.0 International License. 


\section{Political community and transnational citizenship: ethnographic perspectives on a heterogeneous articulation}

\section{Silvina Merenson}

"Political community" and "transnational citizenship" are two of the greatest categories that lead the debates in the field of transnational studies, more specifically in the analysis related to the political practices of the transmigrants regarding the expansion or the exercise of the civic and political rights outside their native countries. From an ethnographic perspective, this article analyzes the existing tensions between both categories. In order to achieve this, it summarizes some of the current debates in literature and mentions the approaches that allow us to think of their uses, meanings and specific practices. In order to point out, if not the autonomy of both concepts, at least the heterogeneous and complex aspect of their practical articulation, we recur to one of the oldest migration processes in the Southern Cone: that of Uruguayans to Argentina.

KEYWORDS: transnational studies, transnational political practices, extraterritorial vote.

Comunidade política e cidadania transnacional: perspetivas etnográficas sobre uma articulação heterogénea - "Comunidade política" e "cidadania transnacional” são duas das grandes categorias que guiam as intervenções e aproximações teóricas no campo dos estudos transnacionais: mais especificamente, nas análises relativas às práticas políticas das e dos transmigrantes relacionadas com a ampliação e exercício dos direitos civis e políticos. Partindo de uma perspetiva etnográfica, este artigo aborda as tensões existentes entre ambas as categorias. Para tanto, são sumarizados brevemente alguns dos consensos existentes na literatura e revisitadas as abordagens que permitem pensar os seus usos e práticas concretas. Com a finalidade de sinalizar, quando não a autonomia de ambas as noções, ao menos o caráter heterogéneo e complexo da sua articulação, recorremos a um dos processos migratórios regionais de mais longa data no Cone Sul americano: o dos uruguaios e uruguaias para a Argentina.

PALAVRAS-CHAVE: estudos transnacionais, práticas políticas transnacionais, voto extraterritorial.

MERENSON, Silvina (smerenson@unsam.edu.ar) - Centro de Investigaciones Sociales, Instituto de Desarrollo Económico y Social, Consejo Nacional de Investigaciones Científicas y Tecnológicas (CIS-IDES/Conicet), Argentina. 
A FEW YEARS AGO, NINA GLICK SCHILLER PROPOSED THE FOLLOWING evaluation of the literature available on transnational migration: "there is currently a large and growing body of descriptive studies of transnational migration. These studies document the many ways in which migrants and their descendants live their lives both within and across the borders of multiple nation-states. Often these studies seem curiously disconnected from both social theory and a series of powerful and contradictory narratives about migration and its consequences" (Glick Schiller 2010: 109). According to the author, two consequences derive from this disconnection: on the one side, with the intention to argue for the long-term tendencies towards integration, "they accept national borders as the borders of society and the necessary institutional nexus for citizenship, democratic rights or a social welfare state" (Glick Schiller 2010: 109). On the other side, "their unit of analysis - often described as a 'transnational community' - becomes a migrating population defined and delimited by communal cultural identities that define a 'transnational space' " (Glick Schiller 2010: 111). Even if these observations could transcend the field of transnational studies, here they will be resumed in order to analyze the political practices of the transmigrants. Specifically, we will discuss the articulations between two key categories of social theory: "political community" and "transnational citizenship."

By the end of the 1990s, the distinction "transnationalism from below/transnationalism from above" organized the first analytical approaches to the study of transnational political practices defined as "various forms of direct cross-border participation in the politics of their country of origin by both migrants and refugees (such as voting and other support to political parties, participating in debates in the press), as well as their indirect participation via the political institutions of the host country (or international organizations)" (Østergaard-Nielsen 2003a: 762). The research focused on the collective actions of transmigrants, such as those related to the political life of their associations and groups, which were classified under the first term of the pair. Meanwhile, the investigations centered on the state and non-state institutional processes related to the rights movements - for instance, the implementation of global national policies by the states, or the action of NGOs on central issues of the global agenda - were classified under the second term. As Schütze comments (in this volume), in recent years the distinction has not varied significantly, at least for research on one of the most explored cases by the existing literature: the political dimension of the migration between Mexico and the United States, which in general has been separated from the civic participation.

Taking the risk of being too schematic, we may find that, in the first case, the investigations aimed to analyze transmigrants' associative forms, the way in which certain circumstances open or close the structures of opportunity 
they find in order to present their demands, as well as the relations between their forms of political participation and the processes of assimilation, integration or incorporation to the "receiving society" (Portes, Escobar and Arana 2008; Østergaard-Nielsen 2003a, 2003b; among others). Meanwhile, in the second case, researchers take notice of the design and the implementation of programs bonding the diasporas, as well as the institutional an legal processes, followed by the expansion of civic and political rights of immigrants and, in a broader and more general sense, of the effect that these institutional transformations have on governability and political systems in the American continent (Calderón Chelius 2010; Itzigsohn and Villacrés 2008; Hallet and Baker Cristales 2010; Escrivá, Bermúdez and Moraes 2009; Lafleur 2011; among others).

As we all know, the distinction "transnationalism from above/transnationalism from below" was subject to different critical revisions (Cortes Maisonave 2005; Caglar 2006; among others). Recently, several works have caught our attention on the daily, interstitial and practical forms of construction and struggle for the definition of rights within migration contexts (Besserer 2013). They constitute forms of circulation that may be understood as processes - open and unfinished - of transmission of ideas, values and resources that go across borders, mobilizing commitments and actions carried out by different state and non-state agents (cf. Boccagni, Lafleur and Levitt 2015). However, when considering the exercise or the struggle for extraterritorial vote, the role of the state and tensions between the categories we will analyze here - political community and transnational citizenship - become unavoidable central matters. Firstly, their interlocutor cannot be other than the state because the demand focuses on inclusion and acknowledgement within its structure according to a conventional understanding of the concept of citizenship, and because what is being questioned are the boundaries and limits that this concept of citizenship imposes on the definition of political community. In order to point out, if not the autonomy of both concepts, at least the heterogeneous and complex feature of their practical articulation, we recur to one of the oldest migration processes in the Southern Cone: that of Uruguayans to Argentina.

The empirical material on which this article is based is the product of multi-located ethnographic research carried out between 2009 and 2015. Following the people, the metaphors, the plot/story/allegory, the life/biography and the conflict, as Marcus (1995) suggests, fieldwork included the interaction with migrants of Uruguayan nationality that carry or carried out transnational political practices from their arrival in Argentina in the late 1940s to the present. That group is composed of men and women from different generations and social classes living in the City of Buenos Aires and its Metropolitan region, as well as the provinces of Entre Ríos, Córdoba and Santa Fe. The article is based 
on 43 in-depth interviews and 22 life stories, though it mainly recovers the ethnographic register of the multiple and diverse public and semi-public types of meeting that mobilize transmigrants and their interlocutors in both Argentina and Uruguay: party and electoral acts, meetings, electoral days, plenary sessions, consulate activities, and social gatherings, among others. The analysis of ethnographic data also contemplates the examination of documental sources, secondary bibliography and several materials produced by the agents which are part of their personal archives. For extension reasons, part of the data and ethnographic descriptions that base this article's reflections refer to previously published works. This article contributes to those analytical proposals attempting to present new explanations and conceptualizations within the context of debates and interrogations with a long tradition in disciplines such as political science and sociology.

\section{THE POLITICAL DIMENSION OF TRANSNATIONAL PRACTICES:} AGREEMENTS AND CONTROVERSIES

Even when the literature on political practices and transnational citizenship covers different levels, processes and agents, there are some common topics. For the purposes of this article, we consider it necessary to mention two of them. The first one indicates that those who carry out some sort of political practice across the borders of nation-states constitute a small proportion among immigrants (Portes, Guarnizo and Haller 2002; Waldinger 2008, 2010; among others). That is to say, it involves a reduced group of migrants - called transmigrants - that, besides sharing a national identification in a certain country of residence (Mexicans in the United States, Colombians in Argentina), assume a political identification that bonds them together and distinguishes them from the rest of their compatriots. What mobilizes these identifications is a topic of debate. Some researchers explain the transnational political practices as "reactive," as a response to difficulties in incorporation or integration into the country of destination (Portes and Rumbaut 1990); others, on the contrary, as a result of multiple insertions that indicate a "hyper-integration" (Lacroix, 2014) of the transmigrants.

The second point refers to the transforming potentiality of transnational political practices. They, according to different investigations, may contribute to the processes of development and democratization in the countries of origin. The transmigrants are characterized as "vectors of modernity and thereby of values and lifestyles associated with the place where they settled" (Lacroix 2014: 664) since they assume an agenda that includes demands such as improvements in governance, a higher respect to human rights, as well as measures that put a stop to corruption and bureaucracy in their native countries (Østergaard-Nielsen 2003b: 22). In the terms of Waldinger, that is because 
"the migrants enjoyed greater opportunities for political action, facilitated by the greater material resources found in their new home" (Waldinger 2014: 11). Then, it is usually said that the capitalization of the discourses and values of liberal democracies by the transmigrants, those which allow them to move forward in the concretion of national goals unreached in their homeland, is a key and transcendental piece of the transnational civic society. By recurring to mechanisms broadly accepted by the international community, such as peaceful demonstrations, petitions, debates and participation in the press, their political practices collaborate in the global monitoring of the governments of their countries of origin (Koinova 2010).

Taking into account the above mentioned, it seems like transmigrants' political actions hold a tight relation with the destination country, that is to say, with learning and obtaining economic, political and moral capitals there. As opposed to that, it is possible that this may help to understand, as Pantoja, Menjivar and Magaña (2008) comment, the surprise in the United States during the demonstrations carried out in the spring of 2006, when millions of migrants and supporters took over the streets asking for a migration reform, thus contradicting a series of assumptions regarding the limited power to enunciate, or the political apathy of the migrants regarding their country of residence. This example reveals that both the sedimentation of political practices of transmigrants oriented towards the country of origin and the problematization of the ways in which the aforesaid actions "give shape" to those democracies are complex questions that should expand our research agenda.

When we pay attention to works focused on demands related to extraterritorial vote, even if the perspectives and interrogations vary, we find that this may be interpreted as a response of the country of origin attempting to mitigate the process of "decitizenization" suffered by the migrants, understanding this as "the loss of belonging to a political community" (Calderón Chelius 2010). That is why the promotion of transnational citizenship, according to Bauböck (2003), requires the "denationalization of the political citizenship," which, even if not necessarily resulting in a real political participation of the migrants, finds in its acknowledgement a strong symbolic meaning that counterbalances the exclusion and stigmatization frequently suffered by the migrants in their countries of residence. ${ }^{1}$ The desire or the concretion of the extraterritorial vote then appears to be a way for the migrants to re-establish themselves at the

1 One of the frequent topics in literature, particularly for the case of Central American and Mexican migrations in the United States, is the low level of participation of the migrants in the elections of their countries of origin, in spite of the continuous claim for the extension of this right. The different explanations include the demand of the vote as a claim of formal or symbolic acknowledgement, beyond a real will of political participation. 
center of their original political community, a goal that is also related to the need of the governments to generate loyalties within contexts where democracies become more competitive every day, as well as to the increasing importance of the remittances in the national balances of most analyzed cases (see Calderón Chelius and Martínez 2003; González 2010; Itzigsohn and Villacrés 2008; among others).

So, the extraterritorial vote does not escape from the paradox that implies the fact of reformulating the terms of the community involved in it while recurring to the classical concept of citizenship, which follows a segmented logic and "contributes decisively to perpetuating vast global inequalities in life chances" (Brubaker 2015: 20). Before resuming these matters based on the case of the Uruguayans residing in Argentina, we will briefly look at some of the conceptual approaches that will allow us to think of the different uses and practices related to the categories under analysis.

\section{POLITICAL COMMUNITY AND TRANSNATIONAL CITIZENSHIP: ARTICULATIONS AND DISCONNECTIONS}

As we saw above, political community and transnational citizenship are two categories - or force-ideas - that guide the interventions and theoretical contributions in the analysis of transnational political practices. Works like those of Bosniak (2000) and Sassen (2010) helped to show that there is not an objective definition of "citizenship" located out there and ready to use. This may refer to a legal status, a system of rights, a form of political activity, an identity, or even a feeling (Bosniak 2000: 452). The recognition of this broad and heterogeneous range (which gives origin to the proposals of "denationalized," "global" or "post-national" citizenship) is possible only if the notion shifts from a normative sense to incorporate the logics at work in the practices related to specific uses. For Sassen (2010), those are the uses that prove the even greater distance between the citizen and the state, and at the same time question the non-critic association between territory, authority and rights, dimensions that constitute the classical definition of community.

Although we don't have the intention to exhaust a very extensive debate, the post-foundationalist idea of community is, above all, anti-essentialist. In it, there is not a substance that defines its substrate in organic, racial, national, blood or natural terms (Groppo 2011). For Espósito, community alludes to a lack, an unsolvable tension between the impossibility of the common and its contrary, which is what preserves the individual life, the reason why the community reveals itself as a burden, debt or an obligation generated by the alien, that is to say, by that which is not "one of our own" or part of a collective or common interest (Espósito 2003). For Laclau (1997), that which creates community, with its institutions, relations and material aspects, is 
speech. In his work, community has a performative feature and it is the result of the struggles to impose senses and limits, that is to say, it is the product of a hegemonic construction and, as such, unstable. For Mouffe (1999), the condition of possibility of a community is exclusion or, put in another way, the existence of an antagonist "other." What I should point out is that all the mentioned cases imply the idea of a community that never reaches a definitive form, but instead builds and rebuilds itself as a result of conflict and not consensus. $^{2}$

Moreover, we may say that, for the post-foundationalist proposal, the disconnection between the limits of the political community and the state borders makes it possible to think that politics are expressed in the construction of the agents, more than in the realization of certain public policies, thus moving the focus from the state to the community (Franzé 2014: 25). As a result of the latter, then there should not be a univocal or automatic bond between community and citizenship from which the extraterritorial vote would derive as an incorporation mechanism or as a community reincorporation. On the other hand, we may understand that the fights related to the exercise of transnational citizenship, instead of weakening, reinforce the authority of the state and the national borders of community, since the state is its irreplaceable interlocutor, and nationality, the argument on which the demand is sustained. It should be noted that, when we mention the state, we are not referring to an extensively revised homogeneous or discreet idea (Das and Poole 2004, among others), but to a political-administrative and organizational network featured by processes of cooperation, negotiation and conflict in which multiple agents interact. As we will see later, here the state is not considered as an object or an arrival point for the actions of the transmigrants, among other reasons, because it has been, like in other cases, a crucial agent in the process for the construction of the demand of civic rights.

\section{PATHS OF BELONGING, INCORPORATION AND RECOGNITION}

For at least three decades, the emigration rate of Uruguay has been one of the highest in Latin America: almost 14\% of the country's population resides in another country, with almost one million Uruguayans living abroad. The transformation of Uruguay's migration pattern, as in the mid-twentieth century it ceased to be an "immigrant-receiving" country and started being a "complete ejector of population,” was analyzed by socio-demography scholars (Pellegrino

2 Although for reasons of space we cannot explore this further in this article, it should be noted that each of these readings assumes a theory of otherness that, at least regarding this point, links the post-foundationalist proposal with the contemporary debates on the notion of culture referred to, among others, in the works of Geertz (1973) and Ortner (2005). 
2003). Soon, at the beginning of the restoration of democracy after the last military dictatorship (1973-1985), the works by Pellegrino and his collaborators aimed to show the quantitative magnitude of this phenomenon. The data indicated that in the period between censuses 1965-1975, around 8\% of the population censed in 1963 had left the country; that $50 \%$ of these leaves were registered between 1974 and 1975, that is to say, one or two years after the coup of June 27, 1973, and that $66 \%$ of the emigrants had left to Argentina (Wonsewer and Teja 1985), being Buenos Aires and the Metropolitan region the main area of settlement.

Despite the presented data, and even though Uruguayan migration in Argentina is since the XIX century one of the most prominent among the countries in the region, the works on this collective are not many, especially if we compare them with those dedicated to other bordering or regional migrations, such as the Bolivian, Paraguayan and Peruvian. The latter, which in general lines share the questions on the multiple forms of xenophobia and stigmatization that affect those collectives, strongly contrast with the literature centered on the Uruguayan case, for which investigators agree on noting their incorporation to the "host society" in a particular way and almost like no other bordering migratory group, as well as the organization modalities that have historically linked them to the civic and political life of Uruguay (Merenson 2015a). Then, the transnational political practices of the Uruguayans in Argentina are not a new phenomenon, but it was the political migration of the 1970s - "exile," in native terms - that gave it another imprint and crystalized dynamics, for example, in the constitution of the Frente Amplio de Uruguay en Argentina (FAUA) at the beginning of the 1980s, and in the consequences of the lack of a mechanism allowing for the vote from abroad ever since.

It should be noted that Uruguay is one of the few countries in the continent that does not have a remote voting system. In spite of the magnitude of its diaspora and in spite of having been a leader in the consecration of rights at the beginning of the XX century and, recently, in the promotion of highly innovative laws, the vote of nationals residing abroad is part of a "grey area" subject to different legal interpretations and political tensions. ${ }^{3}$ Even if the national Constitution does not suspend citizenship (and therefore, the nationals residing abroad keep their voting rights), those who live outside the country can only vote if they "approach," that is to say, if they are in the national territory on election day and if they are listed in the civil registry. ${ }^{4}$ This leads to the fact

3 Among such innovative laws are the equal marriage law, the sexual and reproductive education law and the one that regulates the possession, production and use of cannabis.

4 This registration may be lost in the case of not having voted in two consecutive national elections and, even if it can be recovered, it implies some tedious paperwork. Regarding this, see Taks (2006). 
that the vote of those residing abroad is conditioned by multiple factors, such as the economic possibility to travel to the country and their legal status in their country of destination, among others.

For Uruguayans mobilized in political or civic terms in Argentina that I met during my fieldwork, there is not a clear consensus regarding what defines them as part of a political community, therefore the recognition of the extraterritorial rights by the state is not necessarily a variable that defines their belonging or exclusion, but neither is the place of residence. For some, more than what is established by the law or defined by the territorial location of the people, belonging to a political community depends on a series of practices, principles, values and commitments forged throughout extensive political and migratory trajectories. Meanwhile, for others, community belonging is inseparable from the recognition of extraterritorial civic rights by the state, because belonging is legitimized in a different way, strongly related to the language of human rights and the new forms of governability. The differences between these positions show the heterogeneity deriving from the articulation of the notions that we analyze in this text. At the same time, it confirms that, as we know, the transnational processes do not have homogenizing effects on the agents, but they are deeply affected by their historical context and their territorial, even geopolitical location. We must anticipate that the different readings that we are about to see, even if they indicate different ways of incorporation and belonging to a political community, and therefore different forms of understanding and practicing transnational citizenship, they are not crystalized in confronted groups. Although they are mediated by the same differences, the ones who have different readings compose the same network of political sociability that gathers them in organizations of different kinds of events, and celebrations related to "Uruguayanness."

In other opportunities (see Merenson 2015a, 2015b) we noticed the political dimension of Uruguayan migration in Argentina and explained the historical process that resulted in the constitution of the Frente Amplio de Uruguay en Argentina (FAUA). The Frente Amplio (FA), the political coalition that has been leading Uruguay since 2005, was organized in Argentina during the 1980 s and is the only one of its type, having resisted the passing of time. ${ }^{5}$ Its creation, as described, was part of the political restoration of the democratic transitions in the region, which resulted in multiple commitments and actions by the leaders and activists in the different countries. That is to say, if the transnational activism of FAUA was a "promoting agent" of a democratization

5 In different historical moments, the two traditional parties (Partido Nacional, or Blanco, and Partido Colorado) were organized in Argentina, but they were active for brief periods and, in general, related to electoral times. The extraterritorial organizations were never institutionally recognized by those parties. 
process in the sense proposed by Lacroix (2014), it was not in a single direction (in Uruguay), but in a tight collaboration with Argentine activism and in Argentina. Recently (Merenson 2017) we have described and analyzed both matters based on its most prominent "political remittance" (Boccagni, Lafleur and Levitt 2015): the so-called "Buquebus vote," 6 that is to say, the management of the movement of ideas, capitals, people and votes from Argentina in order to participate in the electoral processes in Uruguay. Thus we explain the way in which this political-electoral participation, thought of and exercised in a collective way, tenses the logic of a liberal reading of the vote - defined as "the highest civic expression of the individual." We also point out its magnitude: from the first elections after the end of the dictatorship (1984), different news media estimate between 40.000 and 50.000 the number of people who arrived in Uruguay to participate in the succeeding electoral acts, mostly coming from Argentina. ${ }^{7}$

During my fieldwork, I came to understand that, for the transnational activism of the Frente Amplio, participation in these "electoral trips" - that is to say, in the procedures of democracy and the formal exercise of citizenship is not enough to explain and legitimize the belonging to a political community. In addition to that, there is the commitment and the active and substantial participation in all the phases of the electoral campaign: from the presence in meetings and public initiatives of the different candidates arrived at the country to the distribution of propaganda in squares and fairs during the weekends. These activities, along with the political reasons, at the same time lead them to sustain a complex and contradictory relationship with the demand of extraterritorial vote promoted by the political force to which they belong. More than a few of them said that, if some "distance voting" mechanism were approved, they would still cross the border to vote. It should be noted that the demand of the extraterritorial vote is part of the FA's agenda ever since its arrival at the executive power, although until this moment it hasn't reached the required consensus to legislate it. ${ }^{8}$

6 Buquebus is the trademark of the transport company that joins the Uruguayan and Argentine margins of Rio de la Plata, the one that is often used by the Uruguayans residing in Argentina to travel in order to vote.

7 For instance, after the approval of the extraterritorial vote in Mexico (2005), from the 12.000 .000 Mexicans established abroad, in the 2006 elections 56.000 citizens registered to vote, of which 32.000 voted effectively. Although the reasons for this scarce participation are well known and have been deeply analyzed (Calderón Chelius 2010), I am still surprised that the net number of voters is lower than the Uruguayans' that travel to vote, when the total number of residents abroad is approximately one million.

8 Until this moment, the two traditional political parties keep their historical position, founded in a possible interpretation of the national Constitution, but also in uncertainty generated by that unpredictable amount of votes, which they imagine mainly for Frente Amplio. 
For those who are an active part of FAUA, especially the ones residing in Buenos Aires, the political trajectories before the exile and their later extraterritorial participation in the phases habilitated by the substantial democracy are two powerful reasons that define the belonging to this community. According to Juan, one of its historical leaders: "it is the activism, the political commitment with the country of your whole life what makes you a part of it. No matter where you are." Consequently, from the perspective of the members of FAUA, "activism" - a synonym of belonging to the political community devoted to arrange a campaign and organize electoral trips - is what defines the deterritorialized boundaries (though not denationalized) of the community. From this perspective, the extraterritorial voting right should not only be achieved but merited; therefore, the criterion of access also works as a closure or end. We should also remark that, given the findings of other investigations, the justification of the voting right is not based on economic remittances -which, besides, are very scarce both in absolute terms and in relation to diverse macroeconomic factors, especially for the Uruguayans established in Argentina ${ }^{9}-$ nor in the interpretation of the law. On the contrary, its legitimacy derives from other matters. Alan's trajectory can help us to understand that.

Alan was born in Buenos Aires a little more than 30 years ago and, practically ever since he was born, he has the Uruguayan nationality. His mother is Uruguayan and ever since he was a child she instilled in him the "love for Montevideo," a city that he visits very often but where he never lived. For more than seven years, Alan has actively participated in the FAUA and integrates the board of directors of one of its most important political sectors. He also participates in one of the radio shows of his collectivity. His dedication to the political life of Uruguay takes a great deal of his daily work and efforts. However, Alan never requested his citizenship that would allow him to vote in Uruguay. When I asked him about his reasons, he told me the following: "I could vote. I'd have to do some paperwork [to obtain the civic credential] and that's it. But, how can I say it? It doesn't seem fair, it's like a lack of respect to those who risked their lives during the dictatorship and one day had to run off [go into exile]. To do everything I do, I don't need to vote." If we consider his words, but especially his practices, Alan's feeling of belonging to the political community is undisputable. However, Alan does not relate that to the legitimacy to vote and be voted for. Although we cannot go further on this subject, it is remarkable how the memories of state terrorism operate, in

9 According to the report of the OIM (2011), for 10 years the remittances represented less than 2\% of the GDI. Particularly, for this case in Argentina, the exchange rate has been favorable to Uruguay for more than a decade, therefore we find the case of families established in Uruguay helping economically their relatives in Argentina. 
this case and in others, over the possibilities of thinking the access to extraterritorial citizenship.

As we mentioned, this is not the only way to weigh the relationship between the exercise of citizenship and belonging to the political community: those who have recently assumed the fight for the consecration of the voting right from abroad propose other possible interpretations. It should be noted that, unlike what happened in other countries of destination of the Uruguayan diaspora, in Argentina the organization related to the specific issue of the extraterritorial vote is comparatively recent. Even if this demand had the support of the FAUA and the consulting committees ${ }^{10}$ from which some active "vote promoters" 11 emerged, it was not until the end of 2014 that some of them were organized in a group called Uruguayos en Buenos Aires por el Voto en el Exterior (Uruguayans in Buenos Aires for the vote abroad). Unlike the case analyzed in the previous section, the reference point of this initiative was not given by the country of residence - in this case, Argentina. Instead, it was generated by the process of nationalization of this demand in Uruguay (Merenson 2016), specifically because of the weight acquired by the extraterritorial vote during the presidential elections of 2014 and the role played by different public divisions. ${ }^{12}$ The state officers were the ones who assumed the task of adding a series of leaders and collectives with a long trajectory in the field of the human rights to the cause of the extraterritorial vote, ${ }^{13}$ something which the associations of Uruguayans abroad could not achieve or envision in the past, as part of the strategy required to install the issue in the national political agenda. Until then, many of their initiatives had followed the path of international denounce, based on the same codification and arguments presented in other countries in similar situations, with the purpose of making the "diasporic bureaucracy" find a local echo. ${ }^{14}$

10 The Consulting Committees (Consejos Consultivos - CC) are spaces of citizen consulting that work in coordination with the consulate bodies in different cities of the world. They were created within the framework of Departamento 20, a bonding program promoted by the Ministry of Foreign Relations in 2005.

11 Calderón Chelius gives this name "to those who show an exceptional political participation" and, by virtue of that, "constitute an exemplary citizenship" (Calderón Chelius 2010: 62).

12 The Direction of Bonding (Dirección de Vinculación) of the Ministry of Foreign Relations was very active in this process. One of the tasks of its officers was the creation in 2014 of the Coordinating Office for Voting Abroad, composed of several small civic organizations around the world.

13 Presided by Belela Herrera, one of the leaders of the Uruguayan human rights movement, the Coordinating Office attracted to the cause different social organizations performing in Uruguay, such as the Federación Uruguaya de Cooperativas de Vivienda por Ayuda Mutua (Uruguayan Federation of Cooperatives for Housing and Mutual Aid) and the Organización Nacional de Asociaciones de Jubilados y Pensionistas del Uruguay (National Organization of Associations of Retirees and Pensioners of Uruguay), all of them with a prominent performance in the conquest of social and political rights.

14 In 2011 and 2012, two Uruguayan lawyers residing in Miami presented a request of precautionary measures before the Inter-American Commission on Human Rights. One year later, in 2013, [continues] 
The mediation of the "diasporic bureaucracy" (Smith 2008), that is to say, of the work of public officers, which consisted in promoting the contact between the foreign collectives and the organizations and social leaders in Uruguay, showed three critical aspects: first, in order to achieve transnational citizenship, their debate had to be nationalized; secondly, in order to legitimate their discussion, they had to free their demand from the influence of political parties and to make their agents "political"; in the third place, in order to conquer a right, they had to fight for other rights too. In other words: the change of strategy proved that the demand for extraterritorial vote would gain space and visibility if the leaders of the local organizations were the ones who assumed the task of meeting with the legislators and leaders of the different political parties represented in the parliament. That is to say, it would gain political density when the requests were legitimized by the voice and trajectories of personalities broadly known within the national context, incorporating the claim - through different collective actions - to the extensive agenda of rights of the Uruguayan society; an agenda that today includes, for example, the recognition and respect of sexual diversity, or the fight against gender-based violence. A proof of this is the adhesion in the social media to the \#NiUnaMenos (Not one [woman] less) campaign by the Coordinating Office for Voting Abroad, or the presence of some of its members in the Demonstration for Diversity in 2015.

The Coordinating Office was present in this annual demonstration organized by the different LGBT groups, showing a giant ballot box with the inscription "Absent Vote" in the middle of Plaza Independencia, civic and political center of Montevideo. Many of the demonstrators took pictures with it: among them, Juanita, a well-known actress and transgender activist. The flyer distributed on that occasion indicated the connection between both fights: "Uruguay has moved forward in its rights agenda, but still has a pending task with the recognition of voting rights for those living abroad. Uruguayan men and women living in other countries are being discriminated, since only those who have the economic means to travel to Uruguay can exercise their right." As we can see, this is a very innovative inscription which indicates an integral idea of citizenship and human rights, with the conviction that "there is not one without the other" (Jelin, Caggiano and Monbello 2011: 10). This action also proves that the performance has gained space as political intervention within the disappointment generated by the political processes and their agents (Rai

a member of the CC in Paris and the collective Ronda Cívica por el Voto (Civic Round for the Vote) composed of twelve CC and some associations of residents - raised a request to the United Nations in order to exhort the Uruguayan government to fulfill the international commitments and have the issue under consideration in the following Universal Periodical Assessment. 
and Reinelt 2015). As we will see below, this was not the only performance related to the vote cause.

The collective Uruguayans in Buenos Aires for the Vote Abroad then emerges within the context of strategic revisions that we have summarized in the previous paragraph. Its leaders, unlike those who constitute the old movement of FAUA, are not part of the 1970s exile, but are mainly those who came in the last decades, generally looking for new educational, artistic and labor opportunities. This middle-class migration is much more cosmopolitan though not necessarily "global" - and less affected by the ideological conflicts prevailing in the previous generations. However, their insertion in the local Uruguayan collective is weak, therefore their ability to convene is usually limited in comparison with those who have been residing there longer and have strong political networks in Argentina. ${ }^{15}$

Both in Montevideo and Buenos Aires, part of the reconfiguration of the demands for extraterritorial vote consisted of emphasizing its "citizen" quality, understanding this as the sum of different "non-partisan wills." Both aspects, repeated in many occasions, operated in the performance organized by the collective in December 2015. Joined under the slogan "We put the heart in the Obelisk," one of the public meeting points of Buenos Aires, its members used the social media to call for participation in an "artistic activity" which consisted of a collective hug. The initiative, promoted within the context of a campaign defined as "voluntary" and "self-sustainable," aimed to clearly mark the political though non-partisan aspect of the action, understanding as the logical counterpart to these affirmations their civic aspect, the one that at the same time was object of claim and dispute. If, as Franzé points out, "the political is the fight around the principles that configure the community, the depolitization consists in presenting these principles as something which is not disputable" (Franzé 2014: 33). Therefore, the performance at the Obelisk politized the notion of "citizenship" and the belonging to a community, but in a different sense to the one we saw among the transnational activism of FAUA, for whom citizenship is inseparable from partisan action.

The aforesaid performance presented the demands for extraterritorial vote within the "empire of feelings" (Sigaud 2004), that is to say, in emotional terms. This was clearly stated in the billboard that announced the event - two hands shaping a heart with the text "We are all Uruguayans" - which replaced the billboard used until then, that categorically stated "Vote abroad now." A three-minute video called "Love for Voting Abroad" resulted from the performance made at the Obelisk. There we can see around 40 people (men and women of different ages) melting in a collective hug, resulting in

15 For an analysis of the political and migration trajectories of those who constitute this collective, see Merenson (2016). 
three circles spinning in opposite directions by the song "Canción con vos," written by a Uruguayan musician living in Buenos Aires. The lyrics of "Canción con vos" (Song with you) synthetizes one of the most frequent images among the migrants in Buenos Aires when explaining their bond with Uruguay, located on the other side of the Rio de la Plata: "Love is the course of a shared river. It crosses many landscapes, but it is still the same river." Neither the performance nor the video record the voices of the participants of that day: that is to say, there are no opinions or arguments about their claim, as in other occasions. On the contrary, the oral speech is replaced by happy gazes, friendly smiles and moving bodies. There is only one final text closing the video: before the acknowledgments to the "huggers," that is to say, those who participated in the action, we can read "Uruguayans' vote abroad is: + rights, +citizenship, +love." "Our love for the vote," would later add one of the activity's organizers, "the love for our families, our communities, our country, our culture."

With this performance, the collective Uruguayans in Buenos Aires for the Vote Abroad publicly established an alternative way of understanding the belonging to the political community, related to the implementation of the right to exercise the extraterritorial vote. From this perspective, its denial or omission has a clear interlocutor - the state - and is adjusted to the classical definition of citizenship; that is why the demand strengthens the national boundaries - though deterritorialized - of the community implied in it. A proof of this is one of its slogans: "We are all Uruguayans; we all have the right to vote."

Like we said, the creation of this new collective is not only based on the structure of opportunity opened in Uruguay after the foundation of the Coordinating Office, but it presents itself as one of its consequences. However, this transformation in the country of origin is also important to the Argentine political scenario, marked by the recent electoral victory and the presidency of the "Cambiemos" alliance, whose campaign was dominated by appeals to the individual and their emotions. Without sharing the ideological background, the aforesaid performance capitalized some resources present in the local context; yet, those public actions and interventions were supported by those who carry out the claim in Montevideo. That is to say that, even if the political actions of the transmigrants are set in the country of destination, it is the country of origin, as Collyer (2008) affirms, that legitimizes them.

The readings and practices of the "activists," "citizens," "volunteers" and/or "huggers" that we mentioned before indicate that the paths for belonging and incorporation in the political community may register different ways and forms. Therefore, their articulation with the way in which transnational citizenship may be practiced is also different. Below, and given the presented case, we present some reflections about it. 
Four major questions led the exploration proposed in these pages. How should we think about the bonds between political community and citizenship within migratory contexts? What notions of community and citizenship do these bonds imply? Is the recognition of the extraterritorial vote a synonym of incorporation to the political community? What paths for belonging, incorporation and recognition do the transmigrants propose? In order to elaborate some possible answers, we begin by taking into account the post-foundationalist contributions, which allow us to approach the data collected in our fieldwork among Uruguayan transmigrants in Argentina. Specifically, we analyze the relations between the exercise and the demands for transnational citizenship - via extraterritorial vote - and the diverse forms to interpret the belonging or incorporation into the political community, by identifying the outstanding differences between the readings proposed by the FAUA activists and the ones proposed by the members of the collective Uruguayans in Argentina for the Vote Abroad.

The differences between both proposals indicate that there is no single possible way to understand the relation between belonging to the political community and the exercise of transnational citizenship, since even the first can go without the second one. We also saw that the demands regarding transnational citizenship, specifically in relation to the extension of the civic rights of nationals abroad, may strengthen the national boundaries - though deterritorialized - of the political community; therefore, they do not necessarily propose the denationalization of citizenship stated by some authors reviewed in the first section of this text. In this case, the strong classical imprint proposed for the articulation of both terms contrasts with that which weighs that articulation in relation to commitments, values and practices linked to the political trajectories before and after the decision to migrate, therefore continuing to act as a factor of delimitation, also deterritorialized, of what belonging to a community is and how it would legitimize the exercise of transnational citizenship.

Finally, there is a concern that flows over the research that started this article and that we can briefly mention, as a form of an open question for future reflections. If, as different authors affirm, the current order of global capitalism is characterized by a growing weakness and discomfort regarding the electoral mechanisms of political representation, and if the discredited perception of citizenship means that the vote can no longer influence fundamental political decisions, since they are no longer made by the parliaments or the governments (Comaroff and Comaroff 2013, among others): how can we read the tenacity in these people's demands? What expectations, desires and imaginaries are involved in the acquisition of this right? It is possible that the empirical answers to these questions result in new approaches to the ways of understanding politics, in times when localization is strongly discussed. 


\section{REFERENCES}

BAUBÖCK, Rainer, 2003, “Towards a political theory of migrant transnationalism”, International Migration Review, 37 (3): 700-723.

BESSERER, Federico, 2013, "Micropolíticas de la diferencia en una comunidad transnacional”, in Alejandro Grimson and Karina Bidaseca (eds.), Hegemonía Cultural y Políticas de la Diferencia. Buenos Aires, Clacso, 263-278.

BOCCAGNi, Paolo, Jean-Michel LAFLEUR, and Peggy LEVITT, 2015, “Transnational politics as cultural circulation: toward a conceptual understanding of migrant political participation on the move", Mobilities, 11 (3): 444-463.

BOSNIAK, Linda, 2000, "Citizenship denationalized", Indiana Journal of Global Legal Studies, 7: 447-509.

BRUBAKER, Rogers, 2015, Grounds for Difference. Cambridge, Harvard University Press.

CAGLAR, Ayse, 2006, "Hometown associations, the rescaling of state spatiality and migrant grassroots transnationalism", Global Networks, 6 (1): 1-22.

CALDERÓn CHELIUS, Leticia, 2010, Los Superhéroes No Existen: Los Migrantes Mexicanos ante las Primeras Elecciones en el Exterior. México, DF, Instituto Mora.

CALDERÓN CHELIUS, Leticia, and Nayamin MARTÍNEZ, 2003, "La democracia incompleta: la lucha de los mexicanos por el voto en el exterior”, in Leticia Calderón Chelius (ed.), Votar en la Distancia: La Extensión de Derechos Politicos a Distancia, Experiencias Comparadas. México, DF, Instituto Mora, 217-267.

COLLYER, Michael, 2008, "The reinvention of political community in a transnational setting: framing the Kabyle citizens' movement”, Ethnic and Racial Studies, 31 (4): 687-707.

COMAroff, Jean, and John COMARoff, 2013, Teorías desde el Sur: O Cómo los Países Centrales Evolucionan Hacia África. Buenos Aires: Siglo XXI.

CORTES MAISONAVE, Almudena, 2005, "La experiencia del codesarrollo Ecuador-España: una aproximación a un transnacionalismo 'desde el medio' ", in G. Herrera, M. C. Carrillo and A. Torres (eds.), La Migración Ecuatoriana: Transnacionalismo, Redes e Identidades. Quito, Flacso, 253-277.

DAS, Veena, and Deborah POOLE (eds.), 2004, Anthropology in the Margins of the State. Santa Fe, School of American Research Press.

ESCRIVÁ, Ángeles, Anastasia BERMúdEZ, and Natalia MORAES (eds.), 2009, Migración y Participación Política: Estados, Organizaciones y Migrantes Latinoamericanos en Perspectiva Local-Transnacional. Córdoba, Consejo Superior de Investigaciones Científicas, Instituto de Estudios Sociales de Andalucía.

ESPÓSITO, Roberto, 2003, Communitas: Origen y Destino de la Comunidad. Buenos Aires, Amorrortu.

FRANZÉ, Javier (ed.), 2014, Democracia: ¿Consenso o Conflicto? Agonismo y Teoría Deliberativa en la Política Contemporánea. Madrid, Catarata.

GEERTZ, Clifford, 1973, The Interpretations of Cultures. New York, Basic Books.

GLICK SCHILLER, Nina, 2010, "A global perspective on transnational migration: theorizing migration without methodological nationalism", in Rainer Bauböck and Thomas Faist (eds.), Diaspora and Transnationalism: Concepts, Theories and Methods. Amsterdam, Amsterdam University Press, 109-129.

GONZÁLEZ, Olga, 2010, "El voto de los colombianos en el exterior: elecciones entre disfuncionamientos y rebusque”, Ciencia Política, 9: 62-77. 
GROPPO, Alejandro, 2011 , "Tres versiones contemporáneas de la comunidad: hacia una teoría política post-fundacionalista”, Revista de Filosofía y Teoría Política, 42: 49-68.

HALLET, Miranda, and Beth BAKER CRISTALES, 2010, "Diasporic suffrage: voting rights in the Salvadoran trans-nation”, Urban Anthropology, 39 (1-2): 175-211.

ITZIGSOHN, José, and Daniela VILLACRÉS, 2008, "Migrant political transnationalism and the practice of democracy: Dominican external voting rights and Salvadoran home town associations", Ethnic \& Racial Studies, 31 (4): 664-686.

JELIN, Elizabeth, Sergio CAGGIANO, and Laura MONBello (eds.), 201 1, Por los Derechos. Mujeres y Hombres en la Acción Colectiva. Buenos Aires, Nueva Trilce.

KOINOVA, Maria, 2010, "Diasporas and international politics: utilizing the universalistic creed of liberalism for particularistic and nationalist purposes”, in Rainer Bauböck and Thomas Faist (eds.), Diaspora and Transnationalism: Concepts, Theories and Methods. Amsterdam, Amsterdam University Press, 149-165.

LACLAU, Ernesto, 1997, Emancipación y Diferencia. Buenos Aires, Ariel.

LACROIX, Thomas, 2014, "Conceptualizing transnational engagements: a structure and agency perspective on (hometown) transnationalism", International Migration Review, 48 (3): 643-678.

LAFLEUR, Jean-Michel, 2011 , “The transnational political participation of Latin American and Caribbean migrants residing in Europe", International Migration, 49 (3): 1-9.

LAFLEUR, Jean-Michel, and Leticia CALDERON CHELIUS, 2011 , "Assessing emigrant participation in home country elections: the case of Mexico's 2006 presidential election", International Migration, 49 (3): 99-124.

MARCUS, George, 1995, "Ethnography in/on the word system: the emergence of multisited ethnography", Annual Review of Anthropology, 24: 95-117.

MERENSON, Silvina, 2015a, "Between brotherhood and exceptionalism: processes of identification, social marking, and justification in Uruguayan immigration in Buenos Aires", Revista Migraciones Internacionales, 8 (1): 9-37.

MERENSON, Silvina, 2015b, "El 'exilio' uruguayo en Argentina: intersecciones entre memoria, ciudadanía y democracia”, European Review of Latin American and Caribbean Studies, 98: 49-67.

MERENSON, Silvina, 2016, "El voto extraterritorial en Uruguay: inequidades y asimetrías en una trama política transnacional”, Revista de Investigaciones Políticas y Sociológicas, 15 (1): 123-142.

MERENSON, Silvina, 2017, "Redes, práticas e remessas políticas: a Frente Ampla do Uruguai na Argentina e o voto transnacional”, Sociologia \& Antropologia, 7 (3): 851-877.

MOUfFe, Chantal, 1999, El Retorno de lo Político. Barcelona, Paidós.

OIM - ORGANIZACION INTERNACIONAL PARA LAS MIGRACIONES, 2011 , Perfil Migratorio de Uruguay 2011. Buenos Aires, Oficina Regional para América del Sur.

ORTNER, Sherry, 2005, "Geertz, subjetividad y conciencia posmoderna", Etnografías Contemporáneas, 1 (1): 25-54.

ØSTERGAARD-NIELSEN, Eva, 2003a, "The politics of migrants: transnational political practices", International Migration Review, 37 (3): 760-786.

ØSTERGAARD-NIELSEN, Eva, 2003b, Transnational Politics: Turks and Kurds in Germany. London, Routledge.

PANTOJA, Adrian, Cecilia MENJIVAR, and Lisa MAGANA, 2008, “The Spring marches of 2006: Latinos, immigration, and political mobilization in the $21^{\text {st }}$ century", American Behavioral Scientist, 52 (4): 499-506. 
PELLEGRINO, Adela, 2003, La Emigración en el Uruguay Actual: ¿El Último que Apague la Luz? Montevideo, Centro UNESCO de Montevideo.

PORTES, Alejandro, and Ruben RUMBAUT, 1990, Immigrant America: A Portrait. Berkeley and Los Angeles, University of California Press.

PORTES, Alejandro, Cristina ESCOBAR, and Renelinda ARANA, 2008, "Bridging the gap: transnational and ethnic organizations in the political incorporation of immigrants in the United States", Ethnic and Racial Studies, 31 (6): 1056-1090.

PORTES, Alejandro, Luis GUARNIZO, and William HALLER, 2002, “Transnational entrepreneurs: an alternative form of immigrant economic adaptation”, American Sociological Review, 67: 278-299.

RAI, Shirin M., and Janelle REINELT (eds.), 2015, The Grammar of Politics and Performance. New York, Routledge.

SASSEN, Saskia, 2010, Territorio, Autoridad y Derechos. Buenos Aires, Katz.

SIGAUD, Lygia, 2004, "Armadilhas da honra e do perdão: usos sociais do direito na mata pernambucana", Mana, 10 (1): 131-163.

SMITH, Robert, 2008, "Contradictions of diasporic institutionalization in Mexican politics: the 2006 migrant vote and other forms of inclusion and control”, Ethnic and Racial Studies, 31 (4): 708-741.

TAKS, Javier, 2006, "Migraciones internacionales en Uruguay: de pueblo trasplantado a diáspora vinculada”, Tehomai, 14 (2): 139-156.

WALDINGER, Roger, 2008, "Between 'here' and 'there': immigrant cross-border activities and loyalties", International Migration Review, 42 (1): 3-29.

WALDINGER, Roger, 2010, "Rethinking transnationalism", Empiria: Revista de Metodología de Ciencias Sociales, 19: 21-38.

WALDINGER, Roger, 2014, "Emigrants and emigration states in historical perspective", Los Angeles, University of California, available at $<$ http://escholarship.org/uc/item/ldm $8 g 1$ pp\#page-2 > (last access February 2018).

WONSEWER, Israel, and Ana María TEJA, 1985, La Emigración Uruguaya, 1963-1975. Montevideo, Banda Oriental. 